\title{
THE PROBLEM OF PERPETUITY IN CASH WAQF
}

\author{
Yusep Rafiqi \\ Lecturer at Faculty of Islamic Religion, Siliwangi University \\ Email: yusefrafiqi@gmail.com
}

\begin{abstract}
In Indonesia, cash waqf began to emerge in recent years in line with the passage of the act of the Republic of Indonesia no. 41 Year 2004 About Waqf, Part Ten, Waqf of Movable Objects in the form of Money (or cash). But, in the act, money that can be donated as waqf property is almost certainly based on its nominal value rather than the real value contained in the currency. This article discusses how nominal or real value is contained in the currency when it is used as a waqf. The research approach in this paper is qualitative description method through content/documents analysis, which is a process to gain a better understanding of the complexity that exists. This research analyzing the contents of various complexities between the understanding of the experts about cash waqf and its relevance to the act and economic empowerment of the ummah. By considering real value contained in the currency, cash waqf can only be executed with gold and silver criteria (full bodied money), not paper money criteria (representative bodied money) due to fluctuations in value. Thus, it is necessary to establish standardization of real value to gold and silver in the cash waqf.
\end{abstract}

Keyword: Waqf; cash waqf; real value

\section{A. INTRODUCTION}

Waqf is one of the unique Islamic economic instruments with large area of ijtihad (Gerber, 1999, p. 85). With its distinctive character as the transfer of ownership of individual property to property ownership to Allah, necessitate the endowment of waqf belong to the eternal public and must remain intact and maintained its source. The transitional form of individual assets into God's assets in waqf can be found in the various definitions of waqf in the perspective of the popular mouslim schoolar (Khadduri \& Liebesny, 2008 , p. 101). The institution of waqf is a perpetual charity in the Islamic system. Waqf is an Islamic economic tool that raises and enhances the socio-political of the ummah (Nurrachmi, 2013). For example the popular definition among Hanafiyah as habs al-'ayn 'alāhukm milk al-lđ̄ ta'đāwa tașaddaq bi almanfa'ah (holding the principal property of Allah's law and giving its benefits) which then bring up to

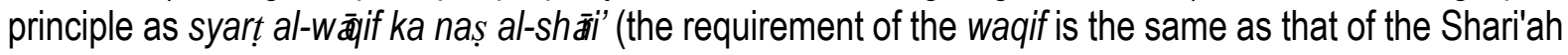
Maker) (Ibn Nujaym, 1999).

In Indonesia, the management of waqf has not been so developed compared to other countries. Although the contribution of wakaf land is so great-the Ministry of Religious Affairs data shows that the number of waqf land in Indonesia is 430,766 locations with an area of 1,615,791,832, $27 \mathrm{~m}^{2}$ spread in 366,595 locations-but very few are productive (Rosadi, Effendi, \& Busro, 2018). This is reinforced by the result of research of Center for Language and Culture (UN) UIN Syarif Hidayatullah Jakarta (Prihatna, Najib, \& Makassary, 2006) shows that wakaf property is more silent (77\%) than productive or productive $(23 \%)$. Other findings show that the greatest use of waqf property is the mosque $(79 \%)$ than the other designated, and more in rural areas (59\%) than urban (41\%) (Dahlan, 2017). 
Mustafa Edwin Nasution and Uswatun Hasanah (Nasution \& Hasanah, 2006) assume that the number of middle-class Muslim population in Indonesia is 10 million with average monthly income between Rp $500.000,00$ (five hundred thousand rupiah) - Rp 10.000.000,00 (ten million rupiah) then can be calculated as follows:

Table of Potential of Cash Waqf in Indonesia

\begin{tabular}{lllll}
\hline Income Level/month & Number of Muslims & Rate of Waqf/month & Cash Waqf Potential/month & Cash Waqf Potential/year \\
\hline Rp. 500.000 & 4 Million & Rp. 5000 & Rp. 20 Billion & Rp. 240 Billion \\
\hline Rp. 1 -2 Million & 3 Million & Rp. 10.000 & Rp. 30 Billion & Rp. 360 Billion \\
\hline Rp. 2 -5 Million & 2 Million & Rp. 50.000 & Rp. 100 Billion & Rp. 1,2 Trillion \\
\hline Rp. 5 -10 Million & 1 Million & Rp. 100. 000 & Rp. 100 Billion & Rp. 1,2 Trillion \\
\hline Totally & & & & Rp. 3 Trillion \\
\hline
\end{tabular}

Source: Edwin Nasution and Uswatun Hasanah (2006)

In Indonesia, there have been several institutions that have implemented cash waqf, at least in the level of waqf in the form of money, such as the Executive Board Mathla'ul Anwar with "Dana Firdaus", Tabung Wakaf from Dompet Dhuafa Republika, Bank Muamalat Indonesia (BMI) with his new institution "Baitul Mal Mu'amalat". Although in its implementation, the management of cash waqf is still not maximal, so until now not yet felt in real by many people. But, at least the effort to empower the cash waqf has begun to be intensified with all its limitations. The problem is, how the model and implementation mechanism of Wakaf Cash Certificate can be applied in Indonesia by involving pre-existing infrastructure and adapting it to the structure of Indonesian society and culture itself. In addition, in the laws and regulations of the government, there is no mention of the intrinsic value contained in the currency. This will affect the perpetuity principle of waqf property.

\section{B. METHODS}

Based on the background of the problems the author describes above, using the deductive analysis, this study is an abstraction formation based on the parts that have been collected, which are then grouped. By using descriptive qualitative method through content analysis approach (Drisko \& Maschi, 2015, p. 87), then found some conclusion about intrinsic and real value in currency in cash waqf action. This relates directly to the principle of perpetuity of waqf property and the distribution of its benefits in the cash waqf. This research requires the direction of substantive theory of the basic (Grounded Theory), namely the study of a large number of data collected and interconnected so that found how 'should' in the act of cash waqf.

\section{RESULTS AND DISCUSSION}

\section{Types of Waqf}

The fiqh scholars use two vocabularies in declaring waqf: the waqf itself (الوقف) and habs (الحبس). In alMu'jam al-Wasiț (Mușțafā, 2008)it is stated that the word habasa which is the verb form of al-habsu means to prevent (mana'a), to withhold (amsaka) or to imprison (sajana). Something that is endowed implies that he should not be sold and inherited. That is, something is controlled by channeling the purpose and benefits only. The word al-ḥabsu which is the gerund form of habasa can mean something that is held back in the stream while the water becomes retained. The word Waqf is derived from the Arabic root verb waqafa, which means' causing a thing to stop and standstill '. It also takes the meanings of 'detention', 'holding' or 'Keeping'. Waqf which (plural: Awqf) is called Boniyad in Iran and habs (plural: ahbas) in North and West Africa (Md. Shahedur Rahaman Chowdhury, Iftekhar Amin Chowdhury, Mohd 
Zulkifli Muhammad, \& Mohd Rushdan Yasoa, 2012). In western traditions some terms referring to waqf or awqâf are Endowment, Foundations, Pious Foundation (Çizakça, 1998), Trust, and Charitable trusts which are all commensurate with generosity. Mundzir Qahaf (Qahf, 2006), with reference to the English Dictionary, The New Shorter Oxford, states that the term endowment is a gift. Included in this term is a dowry or alms for the wife and inheritance left for her. This term also refers to something granted to individuals and organizations. The word foundation is a treasure that is devoted to the interests of the organization / foundation forever.

From the etymological meaning of waqf, both terms in Arabic as well as in English, there are significant differences although the various terms in the two traditions have the same purpose. In Arabic the phrase 'waqafa' becomes the holding and preventing of property from being exploited in private and making it public property (belonging to Allah). This sentence, intrinsically, is an affirmation of the functional dimension and treatment of the 'treasure'. Meanwhile, trust or charity in Western tradition refers more to the personal dimension in the treatment of the represented property. Thus, waqf in Western tradition can mean the same thing as other philanthropic institutions which are all forms of social concern. Meanwhile, waqf institutions in Islamic traditions separate treatment with other philanthropic institutions, such as zakah, infaq, inheritance (w⿱一𫝀口ith) and so on, although all point to the form of institutionalized social care. Recorded in hadith as Issued in Shahih Muslim (4310): "Abu Huraira (May Allah be pleased with him) reported Allah messenger (pbuh) said: When man dies, all his deed breaks down except on three things: șadaqah jāriyah (waqf), useful knowledge and children who always pray". (Muslim, 2012)

The conclusion of the various etymological definitions and the fiqh's perspective can be taken in Arabic intersection as: al-tahbis which means to withhold and prevent, ie to withhold its substance and to prevent it from possession, and al-tasbil which means: releasing the principal benefits of what is something given as donation to be distributed. Various definitions of waqf in the terms of the jurists indicate that the principle of benefit (tasbil al-manfa'ah) of waqf property is the intersection of the various opinions. All muslim scholars agree that channeling the benefits to mawqūf 'alayh is at the substance of the waqf action. Meanwhile, the principle of perpetuity (tahbīs al-așl) waqf property is still a debate, even to this day. Among the debates about the perpetuity principle of waqf property is about the waqf of movable objects.

According to the intersection of various definitions, the discourse on productive waqf continues to grow. Waqf is no longer interpreted as al-tahbiss or holding back, but it is al-tasbill, which means the distribution of its benefits. Waqf objects are no longer seen as endowments of immovable objects (waqf al-'lqār) in the form of land and buildings only. Objects are endowed can be movable and moveable objects (waqf al-manqūl). The immovable object (al-'iqār) is a thing that can not be moved from its original place, like a house and a land or something fixed. Meanwhile, movable or moveable objects (al-manqûl) are objects that can be moved from their original place, or something that can be moved from one place to another such as currency, animals, scales and so on. Furthermore, the scholars differed in terms of the categorization of these two forms of property; whether the object that changes its shape when it is moved is called immovable objects or movable objects such as buildings and trees. In this case, there are two different opinions: first, the opinion of the Hanafite declaring that the object included in movable object (al-manqūl) except when the buildings and trees on the ground permanently. Second, the opinion of Jumhur Ulama other than Hanafite states that the object is included in the category of immovable objects (al-'iqār) (al-Dubyan, 1432).

Mușțafā Aḥmad Zarqā (Zarqā, 1997) states that the waqf of movable objects is divided into two categories: First, movable objects are represented following immovable objects, which include: waqf of 
an area in which consists of agricultural equipment, animals and buildings, or waqf building in it consists of a variety of equipment, or waqf land on which consists of a variety of plants. This type of waqf is legitimate from the point of view of endowments of immovable and movable things at once. Similarly waqf in the form of armaments and armor, the endowments of such movable objects are legitimate according to the sunnah. Second, movable objects are independently represented. Waqfs of movable objects in this category are intended as objects that can be utilized independently as well as books and mushhafs, tools for bathing bodies, ambulances, or anything else that can be used in science.

In terms of waqf of movable objects independently, Zarqā underlines them in two categories as well: First, treasure that traditionally popular in the local community (al-'urf). Waqf in this category is a waqf that does not collide with naș. The rules of figh that support the enactment of the law of waqf of movable objects in this category are al-'dah al-muhakkamah. Secondly, it is an unpopular property among the local people. The waqf of movable objects in this category is like a house tool, an animal. Waqf like this is invalid because basically, waqf must be a fixed and lasting movable object.

From the categorization of waqf objects which are reviewed based on movable or immovable objects and some of the opinions of the experts above, then, cash waqf included in the category of popular objects in the tradition of society (al-'urf) with the provision of not opposite with the texts (naș). This paper will examine some of the problems associated with cash waqf: is it possible that the cash being represented can be immutable if converted into real money? How nādhir requirements are able to manage cash waqf, given the potential of cash waqf is very large, but the empowerment of nazhir waqf not yet optimal compared with Islamic economic instrumentation management.

Hanafiyah impose the waqf of movable objects on the basis of istihsan reasoning. As for Nash syar'i which became the foundation istiḥsān Hanafite is the following ḥadith: As Issued in Bukāhrī (1468) it was narrated that Abu Hurayrah (may Allaah be pleased with him) said: The Messenger of Allah (peace and blessings of Allah be upon him) commanded us to do charity. It was said that Ibn Jamil, Khalid Bin Al Waleed and Abbas Ibn Abd Al-Muttalib were forbidden. The Prophet (peace and blessings of Allaah be upon him) said: He was a poor person, and he was rich by Allah and his Messenger. But Khalid, you are unjust Khalid, he has been donating his weaponry when he has fought in the way of Allah. As for 'Abbas ibn Abd al-Muttalib, he used to have a charity. (Bukhārī, 2000)

\section{The Problem of Cash Waqf}

Directorate of Waqf Empowerment, Ministry of Religious Affairs of the Republic of Indonesia stated that In the context of Indonesia, although the potential of waqf is very large, the development of the management of waqf properties professionally is still slow. This can be traced from the periodization of waqf development in Indonesia which is divided into three period. First, the traditional period. This period is marked by the abundance of immovable waqf property) for mosques, madrassas, cemeteries and social foundations. So that the existence of waqf has not given wider social contribution because only for consumptive interest only. This stagnant period was caused by the freezing of understanding on the things of waqf, Nazhir waqf which is still traditional and inadequate legislation. Second, the semiprofessional period. In the Department of Religious Affairs records, this period is not much different from the first period, it's just that some of the waqf mosques, especially those located strategically, have been developed in such a way by the addition of hall buildings, meeting halls, libraries, educational institutions. For waqf agricultural land, has been developed with the establishment of business units such as rice milling, retail stores and so forth. Third, the professional period. This period is marked by the commencement of nazhir management in a professional manner which has a positive impact on the 
massive waqf movement. In this period also marked the birth of Law no. 41 of 2004 on Waqf. Then came the idea of investment wakaf, which in Indonesia has been started by Dompet Dhuafa Republika in cooperation with Batasa (BTS) Capital.

Discourse on cash waqf have begun in the last few years. This happens as the development of economic and development systems that create new innovations. 'Money' is something generally accepted for the payment of goods and services; and serves as a wealth to its owner (Hasanah, 2011). In Arabic, money is al-naqd (pl: al-nuqūd). The terminology of money in Arabic varies, including: al-Jayyid al-Wazîn min aldarâhim (the good of dirhams), qabdh al-darâhim (reaching dirham), tamyīz al-darāhim wa ikhrāj al-zayf (differentiating dirhams and issuing) (Ahmad Hasan, 1999). Khilāf al-nasi'ah (antonym of credit) or mā yu'thā min al-thamān mu'ajjal al-dirhām (rewarding dirhams with immediate / muajjal) (Abū Su'ūd, 1997).

The word nuqūd is not found in the Qur'an nor the Prophet's hadith because Arabs generally do not use the word nuqûd to show price (al-athmān). The Arabs used dinār-derived from the Roman tradition, Denarius, a name for gold prints to denote a currency made of gold, and dirhām—currency derived from the Greek tradition, Drachma, the name for the printed silver to show the currency of silver. They also use the word wāriq to denote silver dirham, and the word 'ayn to denote gold dinars. The word fulūs, plural of fals, (copper money) is an additional means of exchange used to buy cheap goods (Hasan, 1999). Furthermore, if we consider the opinion of fiqh scholars about the notion of two currencies (naqdan), gold and silver are as follows:

- Imam al-Sharbini say: if it is absolute, then say: I exchange one dinar with twenty dirhams and there is only one currency (naqd) which is not different or some different currencies except that indeed one has become a habit, then legitimate and absolute disappearance of the currency (Hasan, 1999).

- Ibn Qudama, a Hanbalite school states that...and in the case of the opinion which states that infest with a no longer pure currency (nuqud) then the more logical is allowed to infest with impure naqd. Ibn Qudamah reiterates that the charity of treasure (zakat mal) is with gold and silver (Hasan, 1999).

While currency (gold and silver/ naqd) are not reserved for gold and silver coins that are printed/mixed only, but include both. Al-Sharwani, among others, denominated gold and silver coins even though they are not mixed or printed (pure gold and silver), and specializing on (takhsis) what is printed or unmixed, are rejected in the jurisprudence of the jurists (fuqaha) (Hasan, 1999).

Definition of money according to economists, as quoted Ahmad Hasan (Hasan, 1999) from J.P. Crowther is anything that is widely accepted as a means of payment of debts and the payment of prices of goods and services. Nazhim al-Syamsy states that every thing that is accepted by all parties to the legality of tradition ('urf) or the constitutions, or the value of something itself, and capable of functioning as a medium in the process of diversified exchange transactions on commodities and services, is also suitable for debt settlement and liabilities, are included in the cash sphere.

Ahmad Hasan concludes that money can be distinguished from three aspects:

1. Definition of money in terms of economic functions as a standard of value measures, exchange media, and deferred payment instruments.

2. Definition of money by looking at its characteristics; everything that is widely accepted by every individual.

3. Definition of money in terms of legislation as everything that has the power of law in settling all dependents ('ibrah 'al-dhimma) (Hasan, 1999). 
Something considered as 'money' has six criteria: Acceptability and cognizability, Stability of values, the balance (elasticity of supply), Ease (portability), Physical (durability), and Stabilization of the transaction (divisibility). Uswatun Hasanah stated that the type of money is distinguished from two aspects; a) in terms of materials of manufacture; and b) in terms of value. In terms of materials, money is divided into two: a) coins, and b) paper money. In terms of value, money is divided into two: a) full-bodied money, and b) representative full-bodied money or 'money marked' (Hasanah, 2011).

The coin materials are gold, silver, and bronze. While the material of paper money is paper itself. Paper money-according to the issuer-are divided into two: a) currencies, money issued by the government and/or central bank; and b) deposit money is money issued by commercial banks. Full bodied money is money whose value is equal to its nominal value (intrinsic). Full bodies money is only in coins: gold, silver, bronze. While the representative full bodied money is the money whose intrinsic value is smaller than the nominal value. Representative full bodied money has no meaningful value as a non-monetary item, but this money in circulation 'represents' certain amounts of metals at a value equal to the face value of the money. The current paper money do not represent the amount (weight) of certain metals stored in the central bank. Thus, representative full bodied money can not be exchanged for a certain weight of metal in the bank. Ibn Taimiyah formulated that money with low quality (fulus), would kick money with good quality (dinars and dirhams) at that time inflation soar because 'fulus' printed continuously (Rohaya \& Wahid, 2014).

Cash waqf is a waqf in the form of money or cash. Cash waqf according to BWI (Indonesian Waqf Board) is a waqf in the form of money that can be managed productively. The result is used for mawquf alaih. Meanwhile, the definition of cash waqf arranged in the Fatwa MUI signed by Ma'ruf Amien and Hasanudin in Jakarta on 28 Shafar $1423 \mathrm{H} / 11$ May $2002 \mathrm{M}$ stated that (1), cash waqf (waqf al-Nuqud) is a waqf done by a person, group of people, institution or legal entity in cash. (2), Included in the sense of cash waqf is securities.

Tasūlī, in his commentary of Tuhfah al-Hukkm̄m (Tasūlī, 1998, v.2, p: 369), as also cited by Ahmad, defined the meaning of cash waqf in the Maliki School, "as the process of dedicating cash as waqf for the purpose of lending it to them designated as the beneficiaries without interest". (Ahmad, 2015) Also, Zufar Ibn AlHuzail (110AH-158AH) of the Hanafi School defined it "as the process of dedicating cash as waqf and investment of the same so that the profits are used for the waqf's stipulated charitable deeds" (Ibn Nujaym, 1999, p. V:219). In the same vein, Çizacka defines cash waqf as "a charitable endowment established with cash capital" (Çizakça, 1998). Abdel Mohsin Magda (Magda, 2009) defined cash waqf as "the confidence of an amount of money from the founder and dedication of its usufruct according to the founder's condition, in perpetuity to the welfare of the society" (Ahmad, 2015).

The opinion of the scholars who allow the cash waqf as set forth in the book of Risalah fi jawaz waqf alnuqud as follows: figh book.

1. That the permissibility of cash waqf is rooted in Zufar's opinion contained in us-the Hanafiyah

2. Furthermore, the opinion is attributed to the legitimacy of the denomination of dinar money to Ibn Shihab al-Zuhri as quoted in the book of Bukhārī. In the book it is stated that al-Zuhri argues:

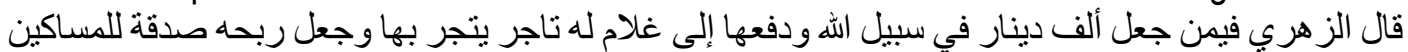

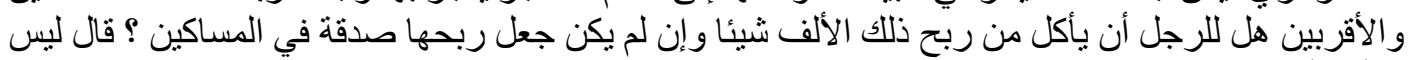

$$
\begin{aligned}
& \text { له أن يأكل منها }
\end{aligned}
$$


'For anyone who wants to make a thousand dinars in the way of Allah, and given to a child who has an entrepreneur, then (the thousand thousand dinnars) is developed to produce a large profit, his profit is given to the poor and the kin. Whether for that person can consume from some of the profits of thousands of dinars, and if not then the alms to the poor. Al-Zuhri said: for the person not (to consume some of his profits) (Bukhārī, 2000).

In al-Mabsūț, as quoted by Abū Su'ūd, Imam al-Sarakhs declares that there is a difference of view between Abū Yūsuf and Muḥammad Ibn Ḥasan al-Shaybānī regarding the waqf of movable property (almanqūI) (Abū Su'ūd, 1997). The answer to that difference of view is' that what has already acted as' urf 'among human beings-including the cash waqf in it, is allowed under the' urf 'consideration. In another book by al-Sarakhsī, al-Muhịț' says Muhammad Ibn Ḥasan al-Shyaybānī, what has become the customs and habits ('urf) of man in the case of the waqf of movable property (al-manqul) Such endowments are permissible under istihsān; such as waqf of saws, axes, crockery, corpses, books and so forth. However, if the waqf is not based on the customs / habits of man, then the waqf is not allowed like a waqf where water from skin or animal.

Taking note of these various opinions, then Abū Su'ūd argues that cash wagf has several restrictions: if it makes the transfer of waqf, its value and its price and what can be bought with value and price is fixed and eternal, then, if the property is utilized but its principal remains, then cash waqf is more important (Abū Su'ūd, 1997). Ibn Taimiyah formulated that money with low quality (fulūs), would kick money with good quality (dinars and dirhams) at that time inflation soar because money fulus printed continuously (Rohaya \& Wahid, 2014).

The use of paper money was known in the 20th century. The marker was when the Bretton Woods system collapsed in 1971. Gold, which for thousands of years became the standard currency (classical gold standard) is replaced with a system of floating exchange rates (flexible exchange rate) which no longer rely on gold. The world then only recognize one paper currency that dominates the trade and become the option of replenishing foreign exchange reserves by various countries, namely the US dollar.This has led to a very hefty spread of inflation around the world (Rohaya \& Wahid, 2014). Many studies of inflation in developing countries show that inflation is not merely a monetary phenomenon, but it is also a structural phenomenon or cost push inflation. This is because the economic structure of developing countries in general is still patterned agrarian. Thus, domestic economic shocks, such as crop failures (due to external factors of excessive season turnover, natural disasters, etc.), or things related to foreign relations, such as the deterioration in terms of trade; foreign debt; and foreign exchange rates, can cause price fluctuations in the domestic market (Atmadja, 1999).

Thus, we can consider some of the values contained in the currency if it is intended to perform the act of cash waqf. There are three aspects seen in the rate of currency:1) nominal value, 2) intrinsic value, and 3 ) real value. The nominal value is the value of money written or stamped in the currency. This value is the most easy to know. Simply by looking at the numbers there, we can already know. Intrinsic value is the value or price of the material used to make the money itself. In most ordinary people, this value is not so thoughtful because in buying and selling, they calculate it based on the nominal value. The meaning of real value is the ability of the power of exchange or the purchasing power of money on goods or services. At a glance similar to the nominal value. But actually different. This difference is influenced by the inflation factor at a time. 


\section{Cash Waqf in the Perspective of the Act of the Republic of Indonesia}

Discussions about cash waqf have begun in the last few years. This happens as the development of economic and development systems that create new innovations. Cash Waqf as a financial instrument, social finance and social banking (social finance and voluntary sector banking) was spearheaded by M.A. Mannan, an economist from Bangladesh. The cash Waqf initiated by Mannan is a new product in the history of the Islamic economy. The financial instruments known in the Islamic economy have been around murabaha to finance the trade and mudaraba or musharaka sectors to finance industrial and agricultural investment. The Bank also refuses to accept the land or other assets which are the property of the waqf to be used as collateral. Because waqf property is not a property right, but the right to use of the waqf's property. (Mannan, 2001)

In the Act of the Republic of Indonesia No. 41 Year 2004 About Waqf, Part Ten, Waqf of Movable Objects in the form of Money, Article 28 stated that Waqif can donate money in the form of money through sharia financial institutions appointed by the Minister. Article 29 states that: (1) Waqf of movable objects in the form of money as referred to in Article 28 shall be executed by Waqif with a Waqif will statement made in writing. (2) Waqf of movable objects in the form of money as referred to in paragraph (1) shall be issued in the form of certificate of cash waqf. (3) The certificate of cash waqf as referred to in paragraph (2) shall be issued and submitted by sharia financial institution to Waqif and Nazhir as proof of delivery of waqf property.

Furthermore, in the Government Ordinance of the Republic of Indonesia Number 42 of 2006 on the Implementation of Act no. 41 Year 2004, declared in Paragraph 3 Movable Objects in the form of Money, Article 22 stated that: (1) Cash Waqf that can be represented is rupiah currency. (2) In case the money to be reproduced is still in foreign currency, it must be converted first into rupiah. (3) The Waqif who will donate the money is required to: attend the Sharia financial Institution Receiver of cash waqf (Lembaga Keuangan Syariah-Penerima Wakaf Uang) the will of the cash waqf; explain the ownership and origin of money to be reproduced; depositing in cash amount to LKS-PWU; filling out the Waqif will statement form that serves as "Akta Ikrar Wakaf" (AIW/waqf statement deed). (4) In case the Waqif can not attend as referred to in paragraph (3) a, then Wâqif may appoint his representative or proxy. (5) Wâqif can declare the pledge of a movable objects in the form of money to Nazhir in the presence of Pejabat Pembuat Akta Ikrar Wakaf (Waqf Statement Deed Official) which then Nazhir handed the AIW to LKS-PWU. Article 23 states that Waqif may award any movable object in the form of money through LKS designated by the Minister as LKS-Cash Waqf (LKS-PWU).

With the issuance of waqf legislation and government ordinance governing cash waqf, society should be encouraged to donate some of their wealth in the form of currency. Some of the benefits to be gained in cash waqf are the amount that can vary. For those who have limited funds can be waqif without having to wait to have the land or buildings to be represented. With the cash waqf, unpaid or unproductive waqf land can be immediately availed by utilizing the cash waqf funds, such as building school buildings, shops or opening agricultural land and plantations as productive waqf assets. Furthermore, cash waqf funds can be utilized by educational institutions, health institutions and so on that suffer from cashflow deficits to avoid the financial difficulties.

There are several problems that must be solved in the context of cash waqf, related to the aspects of waqf culture in this country. First, community knowledge of the benefits of cash waqf still has not moved from conventional waqf (immovable property). For that, the socialization of the authorities in waqf (Department of Religious Affairs, MUI and BWI) should be improved especially for the upper middle class. 
secondly, revamping in the management of nazhir. Third, there must be a guarantee of perpetuity in the real value of the currency by converting on the value of gold and silver.

Inflation indicates that paper money is not capable of being a fair measure. Inflation also shows that the occurrence of decline in currency values, this becomes a tragedy eroding the value of public property. The continuous decline in the assets directed by the paper money caused such huge losses to society (Rohaya \& Wahid, 2014). Thus, inflation in paper money (fiat money) is very influential also in the aspect of perpetuity in the cash waqf. If paper money is not able to be a fair measure of economic transactions - including waqf, it becomes important to measure cash waqf with gold and silver standardization. if someone wants to donate some money in the form of cash waqf, then the bank appointed as the recipient of cash waqf, convert it into gold and silver immediately.

\section{CONCLUSIONS}

The cash waqf issues related to the real value and management (nazhir) can be answered as follows:

1. Cash waqf can only be run with gold and silver criteria (nuqûd/full bodied money), not fulus criteria (paper money or representative bodied money) due to fluctuations in value. Thus, it is necessary to establish standardization of real value to gold and silver in cash waqf.

2. Nazhir as a party that receives wakaf possessions to be managed has the authority to use cash waqf to productive efforts provided that according to sharia.

3. Appointment of Sharia Financial Institutions Receiver of Cash Waqf (LKS-PWU) is a guarantee of waqf investment so that the principle of perpetuity and its usefulness will be sustainable.

\section{References}

Abū Su'ūd, M. ibn M. ibn M. (1997). Risâlah fî Jawâz Waqf al-Nuqûd. Bayrūt: Dār Ibn Ḥazm,.

Ahmad, M. (2015). Cash Waqf: Historical Evolution, Nature and Role as an Alternative to Riba-Based Financing for the Grass Root. Journal of Islamic Finance, 4(1), 63-74.

Atmadja, A. S. (1999). INFLASI DI INDONESIA: SUMBER-SUMBER PENYEBAB DAN PENGENDALIANNYA. Jurnal Akuntansi dan Keuangan Vol. 1, No. 1, 1(1), 54-67.

Bukhārī, M. ibn I. (2000). Șahịḥ al-Bukhārī. Vaduz, Liechtenstein : Jam'iyat al-Maknaz al-Islami,.

Dahlan, R. (2017). IMPRESI NAZHIR TERHADAP PEMAHAMAN WAKAF UANG. AL -URBAN: Jurnal Ekonomi Syariah dan Filantropi Islam, 1(2), 176-188. https://doi.org/10.22236/alurban_vol1/is 2pp176 -188

Drisko, J. W., \& Maschi, T. (2015). Content Analysis. Oxford University Press.

Gerber, H. (1999). Islamic Law and Culture, 1600-1840. BRILL.

Hasan, A. (1999). al-Awrāq al-Naqdiyyah fī al-lqtișād al-Islāmī Qīmātuhā wa Hukmuhā,. Dimashq: Dār al-Fikr.

Hasanah, U. (2011). Aspek hukum wakaf uang. Jakarta: Badan Pembinaan Hukum Nasional, Kementerian Hukum dan Hak Asasi Manusia RI. Retrieved from https://trove.nla.gov.au/version/176481171 
Ibn Nujaym, Z. al-D. ibn I. (1999). al-Ashbāh wa-al-Naẓā'ir 'alá Madhhab Abī Hanīfah al-Nu'mān. Bayrūt: Dār al-Kutub al-Ílmiyyah.

Khadduri, M., \& Liebesny, H. J. (2008). Origin and Development of Islamic Law. The Lawbook Exchange, Ltd.

Magda, I. A. M. (2009). Cash waqf: a new financial product. Petaling Jaya, Selangor: Prentice Hall.

Mannan, M. A. (2001). Sertifikat Wakaf Tunai: Sebuah Inovasi Instrumen Keuangan Islam. Jakarta: Ciber - PKTTI - UI.

Md. Shahedur Rahaman Chowdhury, Iftekhar Amin Chowdhury, Mohd Zulkifli Muhammad, \& Mohd Rushdan Yasoa. (2012). Problems of WAQF administration and proposals for improvement : A study in Malaysia. Journal of Internet Banking and Commerce, 17(1), 1-8.

Muslim. (2012). Șahịḥ Muslim. Bayrūt : Dār Ibn Ḥazm,.

Muțafā, I. et. al. (2008). al-Mu'jam al-Wasīt (1st edition). Dār lhyā̄' at-Turāth al-'Arabī.

Nasution, M. E., \& Hasanah, U. (2006). Wakaf Tunai Inovasi Finansial Islam. Jakarta: PSTTI-UI.

Nurrachmi, R. (2013). THE IMPLICATION OF CASH WAQF IN THE SOCIETY. MPRA Paper No. 44605, Posted 27. February 2013, 11.

Prihatna, A. A., Najib, T. A., \& Makassary, R. al-. (2006). Wakaf, Tuhan, dan agenda kemanusiaan: studi tentang wakaf dalam perspektif keadilan sosial di Indonesia. Jakarta: Center for the Study of Religion and Culture (CSRC), UIN Syarif Hidayatullah.

Qaḥ̂, M. M. (2006). al-Waqf al-Islāmī Tațawwuruh, Idāratuh, Tanmiyatuh. Dimashq: Dār al-Fikr.

Rohaya, R., \& Wahid, N. A. (2014). PENGARUH STABILITAS UANG KERTAS TERHADAP INFLASI DITINJAU MENURUT FIQH MUAMALAH. Share: Jurnal Ekonomi dan Keuangan Islam, 3(1). https://doi.org/10.22373/share.v3i1.1055

Rosadi, A., Effendi, D., \& Busro, B. (2018). The Development of Waqf Management Throught Waqf Act in Indonesia (Note on Republic of Indonesia Act Number 41 of 2004 regarding Waqf). MADANIA: JURNAL KAJIAN KEISLAMAN, 22(1), 1-18. https://doi.org/10.29300/madania.v22i1.881

Tasūlī, 'Alī b. 'Abd al-Salām. (1998). al-Bahjah fī Sharḥ al-Tuhfah: muḥaqqiq Muḥammad 'Abd al-Qādir Shāhīn. Lubnān: Dār al-Kutub al-'Ilmiyyah.

Zarqā, M. A. (1998). Aḥkām al-Awqāf. Dār 'Ammār.

Çizakça, M. (1998). Awqaf In History And Its Implications For Modern Islamic Economic. Journal of Islamic Economic Studies, 6(1), 43-70. 